the jay and the magpie, which are responsible for 80 per cent of the losses of wood-pigeons' eggs.

Dr. Bruce Campbell (British Trust for Ornithology) discussed population problems in a typical insecteating forest bird, the pied flycatcher, illustrated by the ringing and nest-box experiments he was undertaking in the Forest of Dean.

Mr. W. A. Cadman (Forestry Commission) described the progression of wild life at various stages in the development of forests. He said that the pine marten had increased in some Welsh forests.

Mr. Nigel Gray (Imperial Chemical Industries Game Research Station) discussed the relations between game preservation and forestry. He said that good forestry made for good game habitat; but it was essential to have a reasonable mixture of tree species. If the Forestry Commission were to appoint game advisers, it would succeed in greatly boosting private forestry, by showing owners how it could be combined with game preservation.

Dr. I. D. Pennie (British Trust for Ornithology) spoke about the capercaillie and its effects on woodlands. Foresters claimed that in autumn and winter the capercaillie ate almost exclusively the shoots and buds of conifers; but in fact it seemed much to prefer the shoots of transplanted trees in nurseries and plantations to those of naturally regenerating trees. It was thus the shift in forestry practice, from the natural woodland to the artificial plantation, that had transformed this normal member of the woodland avifauna of northern Europe into a forest pest in parts of Scotland.

There were two field excursions during the conference, one under Mr. B. Gale, with a forestry angle, and one under Mr. Edwin Cohen, mainly for birdwatchers.
R. S. R. Fitter

\title{
OBITUARIES
}

\section{Mr. E. Price Evans}

Mr. Evan Price Evans died on April 27, 1959, at his home in Eastbourne, aged seventy-seven. He will be remembered for the part he played in introducing the teaching of plant ecology into schools ; it is probably quite largely due to him that at least in some schools ecological teaching on scientific lines has taken the place of mere 'Nature study'.

Price Evans was a Welsh-speaking Welshman, born at Corris in Merioneth on January 19, 1882. Educated in his native village and at Towyn County School, he entered the University College of North Wales, Bangor, in 1900 and was trained to be a teacher. There he attended the botanical lectures of Prof. Reginald Phillips and Dr. (later Prof.) J. Lloyd Williams. His first appointment was at his own school at Towyn, under the headmastership of a notable chemist, Thomas Jones.

At Towyn he had already experimented with teaching field botany even to quite junior forms, and he later developed this teaching when holding a post at Ryhope, Co. Durham. In his youth, however, he was better known as a footballer than as a scientist and at one time played for Wales in the amateur internationals. From Ryhope he went to Warrington, where he became headmaster of the Grammar School.

At Ryhope from 1913 onwards he began teaching ecology and vegetation mapping to his classes, and his efforts in this direction led him to correspond with the late Sir Arthur Tansley, who was then at Cambridge. Tansley encouraged him to publish an account of his teaching methods in the School Science Review, and later they wrote in collaboration "Plant Ecology and the School" (1946).

Price Evans was a keen student of vegetation on his own account, especially that of his native mountains, which he knew very intimately. He contributed several papers to the Journal of Ecology, of which one dealing with Cader Idris is still the only published account of the vegetation of a geologically and botanically very interesting area and is often quoted. He was an accurate observer and kept notes method. ically; his unpublished note-books are full of valuable observations on the plants and plant com- munities of North Wales. The University of Wales recognized his work by awarding him the honorary degree of M.Sc. in 1933.

During and after the Second World War, Price Evans was a keen supporter of Nature conservation. and he was an active member of the Nature Conservancy's Committee for Wales from its inception until shortly before his death. He had a vigorous and friendly personality and will be much missed.

P. W. RICHARDS

\section{Dr. Z. K. A. Moszynski}

Dr. Z. K. A. Moszynskr, a principal scientific officer of the British Coke Research Association, died at his home in Chesterfield, Derbyshire, on February 13. Zbigniew Konrad Antoni Moszynski was born at Lwow, Poland, on December 16, 1907, and studied in the Department of Chemical Engineering, University of Lwow (1927-34), where he took his diploma (Dipl. Ing.). During 1934-35 he worked in the Laboratory of Potassium Salts, University of Lwow. During 1935-39 he was deputy inspector for civil defence of industry, Polish Ministry of Defence, in the County of Lwow.

In August 1939 he was mobilized and served in the Polish-German campaign, escaping to Hungary, where he was interned. For five months he was assistant to the professor of agricultural chemistry, University of Magyarovar, but in March 1940 he joined the Polish forces in France, being evacuated to England. On behalf of the Polish General Staff he carried out research work in the Mining Department, University of Birmingham, between 1944 and 1945 on the use of carbonized peat/coal blends for mobile gas generators. During 1946-47 he continued and extended this work on the production of reactive carbonized fuels in the Fuel Department, University of Leeds, and obtained the degree of doctor of philosophy.

In September 1947 he was demobilized and in the same year became a British subject. He joined the staff of the British Coke Research Association, at the Midland Coke Research Station, where he was in charge of personnel and acted as secretary of a 